APRESENTAÇÃO

\title{
BRICS: DEZ ANOS E NOVOS DESAFIOS
}

No ano passado, em 2019, o BRICS completou dez anos, o que nos impulsionou a examinar amplamente suas conquistas, seu potencial para o futuro e as limitaçóes existentes no grupo. O ano de 2020 trouxe inúmeros desastres, tanto naturais como provocados pelo homem - os incêndios australianos, a crise iraniana, o desafio de controle de armas de destruição em massa, o Brexit, a guerra comercial sino-americana em curso e, mais recentemente, a pandemia da Covid-19. Tudo isso tem sido um grande teste de estresse para a humanidade, Estados e instituiçóes internacionais. Os poderes e as instituiçóes falharam ao não proporcionar uma liderança genuína a partir de múltiplas crises. Enquanto isso, toda a história de formação e atividades do BRICS é sobre evolução e complementaridade benevolente ao atual sistema de relaçóes internacionais. Todos esses desafios colocam novas tarefas e exigem um papel de liderança mais pronunciado por parte dos países do grupo. Será que isso se tornará possível? O que ainda falta para que o BRICS assuma essas responsabilidades e lidere o caminho?

Esta edição foi elaborada tanto para analisar o passado como para preparar o cenário para o futuro. Este número temático da Revista Tempo do Mundo apresenta dez artigos, que debatem com profundidade diferentes aspectos da articulação política. Essa discussão ganha maior importância em um cenário de generalizada crise de saúde pública, econômica e de governança global, precedida por um acirramento das tensôes comerciais e tecnológicas entre as duas principais potências mundiais - Estados Unidos e China.

$\mathrm{O}$ momento atual exige o uso de todos os instrumentos disponíveis para estruturar a recuperação econômica. O BRICS possui ferramentas institucionalizadas, como a de financiamento com o Novo Banco de Desenvolvimento (New Development Bank - NDB), mas precisa consolidar algumas, como as iniciativas em energia e ciência e tecnologia, e estabelecer outras, como as de agricultura, biodiversidade e respostas conjuntas a crises globais.

O desafio da política externa de seus países é associar as açóes do BRICS, em relação à governança global e à cooperação entre seus membros, com a agenda interna de retomada do crescimento e superação da crise.

O BRICS nasceu de uma demanda real por reconfiguração internacional. Desde sua criação, em 2009, o grupo conseguiu o notável feito de reunir os 
chefes de governo de cinco dos principais países emergentes, de diferentes continentes, de forma ininterrupta, todos os anos. Esse esforço político sem precedentes foi moldando uma agenda bastante ampla, que cresce a cada presidência pro tempore. Em sua última declaraçáo conjunta, de novembro de 2019, em Brasília, os cinco países concordaram em 73 parágrafos de uma extensa pauta de açóes e intençóes.

Para seus membros, o agrupamento se manteve nesses mais de dez anos como relevante instrumento para suas ambiçóes globais em diversas áreas. Sob diferentes governos, foi importante espaço de construção e reafirmação dos interesses nacionais. O potencial do BRICS, porém, ainda é subestimado pelos seus membros, e se faz necessário superar a percepção de divisão e esvaziamento. O caminho para a funcionalidade deve ser o mais simples: os cinco países terem ganhos com o agrupamento. A agenda conjunta deve partir desse ponto.

Em relação à retomada do crescimento econômico no curto prazo, há temas em que o BRICS possui agendas relativamente definidas, como financiamento, energia e ciência e tecnologia; elas, contudo, precisam ser mais bem executadas. Outras temáticas devem ser fortalecidas ou estruturadas, como a agrícola e o comércio de alimentos e o aprofundamento do diálogo e a cooperação em matéria de biodiversidade.

$\mathrm{Na}$ cúpula de novembro de 2019, foi reafirmada a necessidade de maior participação dos países em desenvolvimento nas cadeias globais de valor, na governança global. Os cinco países acordaram continuar a cooperar no Grupo dos Vinte (G20) e a promover os interesses dos mercados emergentes (EMEs) e dos países em desenvolvimento, que declararam estar convencidos de que a contínua implementação de reformas estruturais aumentará o potencial de crescimento. Os anúncios de açóes concretas, porém, ficaram restritos à abertura de escritórios regionais do NDB e às suas atividades nos países-membros. Em 2019, foi criado o Escritório Regional das Américas em São Paulo, com seu subescritório em Brasília, e neste ano serão abertos mais dois escritórios regionais do NDB, um na Rússia e outro na Índia.

Deve-se dar especial atenção à Rede de Inovação do BRICS (iBRICS), com a adoção da Nova Arquitetura em Ciência, Tecnologia e Inovação (CT\&I) - que será implementada por meio do Comitê Diretor de CT\&I do BRICS -, e à Plataforma de Cooperação em Pesquisa Energética do BRICS, para garantir que ambos os instrumentos tenham açóes sinérgicas com as políticas internas de recuperação do crescimento.

Em 29 de abril de 2020, foi realizada, por vídeo, a Conferência Extraordinária dos Ministros das Relaçóes Exteriores do BRICS sobre a Covid-19, presidida pelo chanceler russo Sergei Lavrov, com a participação de seu homólogo chinês Wang Yi, do ministro das Relaçôes Exteriores brasileiro Ernesto Araújo, 
do ministro dos Negócios Estrangeiros indiano Subrahmanyam Jaishankar e da ministra das Relações Internacionais e Cooperação sul-africana Naledi Pandor. Essa iniciativa, ainda que com tímidos efeitos para seu objetivo inicial, mostrou a vontade de cooperaçáo entre os países e pode se repetir para a construção de uma agenda de recuperação econômica pós-Covid-19.

A diminuição do comércio internacional, dos investimentos diretos externos e a saída de capitais são fatores que retroalimentam a crise econômica. Parte das significativas restriçóes ao crescimento do Brasil e de outros países se expressa no setor externo.

A recuperação econômica pós-Covid-19 deve enfrentar problemas que não dizem respeito somente à pandemia, mas também agravam nossas perspectivas de desenvolvimento no longo prazo. Os dez artigos reunidos nesta publicação têm o objetivo de efetuar um balanço das atividades realizadas pelo agrupamento na última década e, ao mesmo tempo, contribuir para o fortalecimento do bloco nesse difícil momento da governança global e da economia mundial.

Os primeiros cinco artigos são contribuiçóes de participantes do Conselho de Think Tanks do BRICS, sendo um artigo de cada país-membro, e abordam diferentes e importantes temas da governança global e da cooperação internacional. $\mathrm{O}$ artigo dos russos Georgy Toloraya e Victoria Panova trata da segurança global, analisando as ações do BRICS e a posição de seus cinco membros. O texto de Zhao Zhongxiu e Lan Qingxin, da China, debate a cooperaçáo no BRICS em relação a comércio e desenvolvimento. Os indianos H. H. S. Viswanathan e Mihir Swarup Sharma discutem os desafios da multipolaridade e da globalização, focando em diversas instituiçóes de governança global e em como o BRICS está se esforçando para superá-los. A ampla agenda social do grupo incluindo desenvolvimento social, educaçấo, saúde e cultura, é o tema da contribuição dos sul-africanos Godfrey Netswera, Jaya Josie, Philani Mthembu, Elias Phaahla e Idah Makukule, que abordam a questão em termos comparativos. Por fim, o brasileiro Luis Claudio Kubota apresenta o progresso de cooperação do BRICS em CT\&I ao longo dos anos, ressaltando o desenvolvimento de cada país e comparando a sua evolução com a de outros países e blocos.

A Revista Tempo do Mundo completa este número com outros cinco artigos sobre o BRICS submetidos por autores de diferentes instituiçóes de pesquisa por meio de nossa plataforma digital. Krisley Mendes e André Araújo Luchine, da Universidade de Brasília (UnB) e Ipea, analisam a evolução, a estrutura e a intensidade de medidas não tarifárias (MNTs) incidentes no comércio de produtos agropecuários, de 1995 a 2018, entre os países que compóem o BRICS. Ana Saggioro Garcia, da Universidade Federal Rural do Rio de Janeiro (UFRRJ), avalia os arranjos institucionais, os atores e os impactos dos investimentos 
da China no Brasil, na África do Sul e na Índia. Karin Costa Vazquez, da Universiade Fudan (China), analisa o NDB do BRICS. Juan Sebastián Schulz, da Universiade Nacional de La Plata (Argentina), examina os dez anos do BRICS sob a perspectiva da construção de uma governança global multipolar e da crise de hegemonia ocidental. Por fim, Robson Cunha Rael, do Grupo de Estudos e Pesquisa em Segurança Internacional (Brasília), pesquisa os padróes de votação de cada membro nas resoluçóes da Assembleia Geral das Naçóes Unidas sobre a reforma da ordem internacional, inferindo que os países do BRICS possuem interesses comuns.

Com este número temático da Revista Tempo do Mundo, o Ipea busca cumprir sua missão de produzir e disseminar conhecimento sobre temas fundamentais para as decisões estratégicas do Estado brasileiro e reforçar a difusão dos debates realizados no âmbito do Conselho de Think Tanks do BRICS, presidido pelo instituto em 2019. Espera-se que esse conjunto de artigos contribua tanto para a análise sobre os dez primeiros anos do BRICS como para a reflexão de seus desafios, que são ainda maiores diante dos diferentes aspectos da crise atual. Espera-se, enfim, que as reflexóes trazidas neste número estimulem propostas mais ousadas a serem consideradas por autoridades e comunidade epistêmica para superar o desafio de curto prazo da Covid-19 e alcançar os objetivos universais de bem-estar comum, respeito mútuo e compreensão.

Ivan Oliveira (Ipea)

Coordenador deste número

Victoria Panova (NKIBRICS, Rússia)

Coordenadora deste número

Pedro Silva Barros

Editor da revista 